\title{
Can María Speak?: Interpreting Ixcanul /Volcano (2015) from a decolonial perspective
}

*This is an Accepted Manuscript to be published in the Journal Studies in Spanish and Latin American Cinema, entitled "Can María Speak?: Interpreting Ixcanul / Volcano (2015) from a decolonial perspective” by Intellect in July 2018. Do not quote without permission.

Amanda Alfaro Córdoba, University College London and Universidad de Costa Rica

\begin{abstract}
This article explores, describes and analyses the material, linguistic and cultural framework in which the central conflict in Ixcanul/Volcano (Jayro Bustamante, 2015) and its mise-en-scène operate, considering the film as an example of an intertextual practice that succeeds in connecting oral and dramatic traditions to a filmic register. By analysing how the film aims to be realistic and locate itself within a contemporary Guatemalan context, this analysis argues that, due to the film's political intentions, themes and intended audience, Ixcanul challenges several power structures that preclude decolonial dialogue in the country. Furthermore, by describing how the subaltern subject, María, endures and resists strategies of invisibilization, this article reads Ixcanul in light of analytical tools drawn from postcolonial and decolonial frameworks to disentangle the structures of domination - the coloniality of power - represented in the film.
\end{abstract}

\section{Keywords:}

Coloniality of Power

Indigeneity

Subaltern Studies

Central America

Cinema

Feminism 


\section{An intercultural production}

The mise-en-scène of Ixcanul/Volcano (2015) displays a particular density as a result of the intercultural negotiations present within both its production and narrative. It deciphers hermeneutic codes through its representation of the subaltern and how this group acts according to the cyclical logic of Mayan time. This rounded logic is staged through births, harvests, lunar cycles, volcanic offerings (religious rituals), verbal language and cinematographic montage, the latter being the only register external to the historic and contemporary cosmovision of the Mayans. It has been noted that Ixcanul was produced by a transnational and multicultural $\mathrm{crew}^{1}$, which supported the almost entirely Kaq' chikel$^{2}$ cast (Coroy, Telón and Antún leading) by creating filmic tools collectively - scenes, dialogues and plot twists - and thus achieving a rhetorical density within the script and narrative arc that is embedded in the Mayan cosmovision. Said tools were facilitated by funds and resources external to the Mayan community. By encompassing the film's technical production to a predominantly Mayan mise-en-scène, Ixcanul connects the film's materiality to Mayan cultural and linguistic codes rarely represented by the filmic medium. This collaboration requires a semantic negotiation that runs the risk of distorting the original voice, and it is this subaltern voice which I further examine.

This article contends that La Casa de Producción - the team behind the making of the film - contributes to, as Charlotte Gleghorn states, 'unsettl[ing] dominant colonial narratives of indigeneity' (2017: 183) by re-articulating the Mayan cosmovision. This is no minor task, considering the numerous layers that surround narratives about indigeneity: language and cultural codes are only part of the biases that sustain aggressive material and discursive control over the community portrayed in this film. The uneven relations the Kaq' chikel in particular, and the Mayans and indigenous people in general, endure are shown on and around Ixcanul's screen. 
To highlight and transgress this hostile environment, the crew effectively overcame three obstacles: the material, the discursive and the linguistic. This article explores, analyses and describes the three elements, considering the film as an example of intermedial practice that succeeds in connecting oral and dramatic traditions to filmic registers, enabling a dialogue through its political intentions, themes and intended audiences in order to challenge some of the power structures that hold back decolonial dialogue in Guatemala. Throughout the next sections I examine the scope of María's voice and the process of bringing it out through intermedial representation, before briefly exploring the subaltern's voice through concrete examples from the film.

\section{Resources for an intertextual representation}

The film's language and structure build a cadence that forces the viewer to watch it as a diegesis guided by the mores and actions of the Mayan characters. In a country where the ladinoindigenous dichotomy is the basis of exploitative social relations sustained by land distribution failures at the expense of the indigenous population's workforce (Salguero Rodas 2016, 402), it is important to note that speaking Kaq' chikel - a language native to roughly half a million speakers - was made a basic requisite to play the leading role in the Ixcanul. This decision was strategic and aimed to achieve the unique cultural diegesis attained by the film: while none of the technical crew's members were of indigenous origin, the fact that most of the professionals involved in the film's production were not ladinos successfully erased (or nuanced) the ladinoindigenous dichotomy which otherwise might have caused tensions (Bustamante 2015a). In the director's view, the multicultural origins of the technical crew contributed to smooth the relationship between cast and crew, which bridged the gap between the need for skilled technical 
personnel and the expression of the Mayan point of view and voice. The team's agenda and the filming process were important in order to avoid the tendency within hegemonic media representation that, according to Gleghorn, 'remains to this day saturated with condescending and violent portrayals of Indigenous people' (2017: 168), while also running the risk that the reenactment of their stories will become 'complicit with the ethnographic tendency to fixate on an existing reality anchored in the past' (Marguilies 2011: 6). This representational trend continues to paralyse the necessary 'community renewal, dialogue and esteem' that practitioners and viewers strive for in Guatemalan, and more widely, Central American and Latin American societies (Gleghorn 2017: 172).

$\$ 8000$ US of funding from Cinergia - in 2014 - kick-started the original idea for the film (Fundacine 2015) as well as the voluntary work of a fifteen-person crew, which operated as technical support. Bustamante also withdrew a 30,000 Euro loan from a French bank, which he describes as a highly risky scheme: '[N]ever in my life had I had so much money in my hands, and I took it without knowing how I was ever going to give it back' (Bustamante 2015b). On the other hand, many professionals were involved out of enthusiasm, and the director believes the film received such goodwill 'just on the basis of pursuing the Guatemalan film industry I believe we are all craving' (2015b: min. 2:13). Bustamante extends his description of the film's production stating 'the task of placing monetary value on all that voluntary work undertaken within the film is a serious one [that eventually had to be faced], as the French co-production team managed their own numbers and wanted their counterparts to match those financially' (Bustamante 2015b: min. 3:57). The film's funding started with the Central American scheme that granted a small sum for the basic post-production, while it shared the first cut of the film with key people from international film festivals; in Bustamante's words: 
It all started with Cinergia. Through Cinergia very important people from international film festivals could see the film, these people started to follow the film and speak about it more when we got to San Sebastián, which really was the catapult for us, and people came to see the film because they were curious about 'Central American' film.

(2015a, min. 13:22)

The detailed work on digital sound and image was financed with the investment from the aforementioned team. After postproduction, the cost of making the film is calculated to have been around half a million US dollars (Bustamante 2015a: min. 5:13), matching gross revenue of US\$295,157 from the global box office (Mojo Box Office). The collaborative production model resulted in the film being the most successful case of an art-house Central American film to date: besides the Alfred Bauer at the Berlinale Festival, more than fifty awards are now part of Ixcanul's accolades (Cortés 2018). Such prizes gained access for this film to numerous film festivals in four continents, which in turn resulted in global distribution through academic and commercial video on on-demand platforms as well as via DVD release in eighteen territories. ${ }^{3}$ The film was shown in Guatemala, where it had around 9,000 commercial spectators in six weeks, as well as 2,500 teenagers from various ethnicities on a two-month tour sponsored by the United Nations Population Fund (Sánchez 2017). It was screened in Costa Rica during four weeks in five theatres, attracting 6,618 viewers (Avellán 2016). Although it is uncertain how many Kaq' chikel speakers have seen the film (Sánchez, 2017), its success - which is unprecedented compared with any previous Central American film - has positioned the Mayan plot as an influential cultural reference for the region. This demonstrates the ways in which material obstacles were overcome through the use of film funds and festival distribution, since no other Guatemalan film - made in any language - has won so many prizes. 
Originally conceived as the story of a Kaq' chikel character, Ixcanul was inspired by an anecdote told to Bustamante's mother - which he asserts is true - in the area around the Atitlán Lake Basin, when she was working as a health professional in the 1980s (Bustamante 2015a: min. 8). The real life María requested anonymity, but agreed for the story to be told as she thought it was not just her story, but that of many Mayan women (Bustamante 2015a: min. 9). Ixcanul's plot is structured in three acts that build into both the portrayed conflicts: the first shows María's attentions towards and attraction to Pepe (18), a young day labourer who is always talking about going to the United States, a place with money, gardens, houses and cars; while her parents have arranged her engagement to the farm manager, Ignacio (34), the coffee farm's administrator, a widower and father of three children. The first act starts chronologically, when both women are breeding the hogs they would then prepare for the meal in Ignacio's honour for the engagement ceremony; it focuses on María's split attention, her brief relation with Pepe, and ends when she is intercepted by Ignacio on her way to follow Pepe as he leaves the village. The second act demonstrates the limitations language and illiteracy place on the main characters. It shows the development of María's pregnancy and how her parents deal with this new circumstance: María asks her mother for help and at first Juana tries to make her abort the foetus, yet when they do not succeed, they try to hide the pregnancy from Ignacio. The middle act ends when María collapses after being bitten by a snake in an attempt to expel the reptiles from the harvested field. The venomous incident takes her, still pregnant, to a hospital in the city, which composes the third act - the episode of the baby's disappearance: from the deceit at the hospital to María's acceptance and wedding to Ignacio. This last episode is also the real life María's story, while the previous two are additional fictions plotted by Bustamante in 
collaboration with the cast and which, I would argue, are inspired by the community's collective memory and oral heritage.

For Ixcanul's production, once the script was written, the crew first arrived to the Atitlán Lake Basin and attempted to hold a casting session in a $\mathrm{K}^{\prime}$ iche community ${ }^{4}$ only to find out that few women would be allowed - by a man, be it their brother, husband, son or father - to travel to the cinematographic setting at the Pacaya Volcano, 150 kilometres away from the Lake's communities, and remain alone on site for the weeks needed for filming. Bustamante highlights how important it was to acknowledge this patriarchal stance in the filming and scripting process as 'the film is precisely about that'. María Telón, an actress at the Kaq' chikel community theatre who had previous on-camera experience in the film Polvo (Hernández Cordón 2012) and happened to be a widow, thus a free woman, became the guide for the next casting session with a different indigenous community.

In terms of the linguistic obstacles that had to be overcome, every aspect of the film's structure and dialogue was negotiated between the technical crew (particularly the writer/director) and the performers. A crucial feature of these negotiations was the film's title, as the word Xcanul means 'the internal voice of the mountain that is boiling and looking for eruption' in Kaq' chikel. It could have been written as a naked noun but Bustamante decided to add the $I x$, as it is the feminine prefix in the language so it really means the 'female internal voice of the mountain that is boiling and looking for eruption', or the female volcano (Pitney 2016). Furthermore, Bustamante explains that the film's language went through a detailed crafting process since he first wrote the script in French when he started looking for funds in France (Bustamante 2015b), before translating it into Spanish in order to work in Guatemala. It was after the crew did the casting that one of the actors then translated this script into Kaq' chikel 
(Bustamante 2015b). ${ }^{5}$ The fourth step was to offer the lines to the actors who would then consider them and say them on their own terms, before finally transcribing this version so it was available for the cast and crew to memorize (Bustamante 2015b). This process took three months and resulted in the cadence of the performances: the actor's speech and pace, which is slow and constant, the silence with which they answer questions that are crucial for the plot and the conviction with which they perform the tasks that relate them to nature all establish a rhythm far from the common speed associated with urban Guatemala, and particularly those sites traversed by motors, digital technology or electronic devices. Moreover, the meaning given to natural cycles - lunar, harvests, pregnancies - highlights the prevailing circular logic of the community we see on screen. The world depicted in the film is carefully protected from the world we understand as Western, as it encapsulates the characters in the village at the skirts of the volcano. A single cemented road appears slowly through a tilt shot at minute 40 (Image 1) when the frame is following María using a wide angle shot as she tries to run after Pepe and is caught by Ignacio. At the end of the story, the roads to the hospital and the hospital itself unveil a Western world rather distant from the Maya diegesis and to which Juana, Manuel and María have no access.

\section{$<$ INSERT FIGURE 1>}

The indigenous cast stages the specific references to the Mayan cosmovision. Juana prays to the deities (earth, wind, water, volcano) for her home, work and daughter, engaging in a prayer to the spirits, thanking them for all the blessings. Later, the Mayan priest thanks the skyearth cited in Mayan documents, the best preserved of them being the Popol Wuj. The Popol Wuj is a collective transcription of various tales describing Mayan origins, the sky-earth's cosmogony 
(the K' iche way of saying 'world' [Tedlock 1985: 12]) and the mythical elaboration of the $\mathrm{K}^{\prime}$ iche's migration. It describes how the Hero Twins, Junajpu and $\mathrm{Xb}^{\prime}$ lanke, defeat the lords of Xibalbá - 'the place offear in K'iche' (Arias 2012: 91) - who had thought of themselves as a false or weaker moon and sun (Sam Colop 2008: 15). The Hero Twins are on their way to harvesting the corn seeds from which humans originate; Xibalbá is 'simultaneously the place of death as well as the space underground where life germinates' (Arias 2012: 92). Despite the challenges of finding written references for the film's representation of the Mayan cosmovision given the meagre Mayan bibliography, I argue that the collective memory represented in the film connects to the best-preserved Mayan document. Ixcanul's plot is intertextual the Hero Twins' story, where they succeed in overcoming obstacles their dual fathers had previously failed and thus outwit and destroy the lords of Xibalbá (Arias 2012: 91). Just like the Hero Twins, María undergoes a series of trials to gain her family's right to maintain their jobs on the farm. The trial is revealed in the narrative first as a way for her to gain freedom, away from an ambiguously unwanted pregnancy, and then through the cleaning of the earth by ridding it of the snakes that affect the harvest. A key code within the story are the lunar cycles Juana mentions twice to María. As a transcription of ancient collective memory and knowledge, Luis Enrique Sam Colop foregrounds how the Popol Wuj describes 'the Orion, Ursa Major and Ursa Minor constellations leaving proof of the Mayan mathematic knowledge of time' (2008: 17). Despite her illiteracy, Juana's knowledge of the lunar cycles comes from the oral transmission of that same heritage once transcribed as the books (Wujs) as 'weaving,' itself a metaphor for 'social fabric' (Popol) (Arias 2012: 90). This interpretation of the hieroglyphs and pictography drawn around 1550 to 1555 in Santa Cruz del Quiché shows that 
employing a Latin alphabet $[\ldots]$ became the foundational manifesto of resistance for the Mayab communities who had survived the destruction of their cities and their culture, the rape of their women, and the enslavement of their men, and in the fifty years following the [encounter with the Spanish newcomers], they lost approximately six-sevenths of their total population.

(Arias 2012: 92)

In this assertion, Arias also reminds us that ' $[\mathrm{t}]$ hose who survived were forced to accommodate their understanding of the world to new cultural realities alien to their beingness' (2012: 92). This cultural shift brought ladinos to the heart of the Guatemalan hierarchies (Arias 2012: 88); nonetheless, Mayan memory remains alive through oral patrimony and this cultural inheritance is represented by Juana's dialogue, speech and rituals. The first spiritual intention, described previously as the volcano offering (see figure 2 below), represents Juana's traditional/learned practice; however, the most consistent register by which the cast stage its culture's vitality is the use of the Kaq' chikel language.

$<$ INSERT FIGURE 2>

Language appears as the key to decipher Juana and María's voice and it drives the film towards a cultural debate as the words and syntax of Kaq' chikel vary from one group of speakers to another. The writer/director explains his understanding of Kaq' chikel is rather limited, as his own Nana prevented him from practicing it, fearing he would be discriminated against. In a second example he also underlines the reversal of this situation due to the film's success: María Telón's children, having 'distanced themselves from the Kaq' chikel language, as they feared 
inheriting the discrimination derived from the racism intrinsic to the history of the indigenous language, started to reconsider practicing their native language once they experienced the film's success' (Bustamante 2015a). Moreover, language reveals the characters' cultural belonging and world view. Throughout the entire film this belonging is expressed by way of the main language spoken and it demonstrates the political questions surrounding it. The dialogue between María and Pepe in the first scenes evidences this: while María asks Pepe why he would like to go to the United States, he describes the wealth of that other space. When he highlights the importance of learning English in the utopian country, María timidly says 'you'd better learn Spanish before thinking about English', advice to which Pepe answers with the rigid dictum: 'it's because of people like you this country is stuck'. The brief discussion between the lovers exposes the political discourse around language practice: while they see their mother tongue as insufficient, María interprets Spanish as a language of promise, while Pepe fixes upon the idea of jumping directly to the next hegemony.

\section{The subaltern's journey and voice}

Since the 1980s, critiques and analytical tools derived from postcolonial theory have offered innovative analyses of capitalism, modernity and European colonialism, on the one hand, and, on the other, some of the boundaries around which national belonging or nationalism has been conceived (Mendoza 2016). The focus has switched from the ambiguous 'imagined community' to the social and economic circumstances that mandate the various aspects of colonial and capitalist domination. Gayatri Spivak's 1983/8 influential essay on this topic, Can the subaltern speak? discussed the ambiguous nature of this rhetoric when enunciated through language or categories using a Eurocentric perspective. Spivak's theory expounds upon the 
notion, or even the possibility, of whether the subaltern has a voice and, in particular, the catch22 situation whereby if the subaltern achieves a voice, he/she at that point ceases to be a subaltern. This discussion is particularly relevant within film studies as Mette Hjort argues, since the

transformative effect of globalisation on the international motion picture industry has had other significant implications for the nature of national film industries and film policy [where] the traditional binary model that pitted an essentially commercial, free-market and internationally oriented industrial model (Hollywood) against a culturally-informed and state- subsidised model (European national cinemas) has been superseded by a 'new international division of cultural labour' (Hjort 2007, p. 9).

The overlooking of the international division of cultural labour is key to understanding why the struggles for representation within intellectual, economic and cultural (filmmaking) history have become invisible. The characters from cultures that occupy the wrong side of the labour division have been historically poorly represented, if at all. La Casa de Producción reverts this exploitation by bringing resources to a community hitherto deprived of filmmaking funds and technical practices.

Twenty years after Spivak's proclamation, the Latin American modernity/decoloniality movement reconfigured this discussion of subalternity and staged it in the context of Latin America (Quijano 2000: 210). This is not a minor detail: the coloniality of power and its theoretical frame transported the focus from the metanarratives of English and French colonialism to their Portuguese and Spanish equivalents, where much of the colonial repression had been based on the explicit exigency that the allies of the colonial powers would switch religion, language and thus ideology. Throughout the Spanish and Portuguese colonies, race 
would determine - and be central to the question of - who had access to full rights; this exploitative relationship continued within the republics that were formed in the nineteenth century and a system of exclusion emerged. ${ }^{6}$ Coloniality's premise was to separate the human from the non-human and determine those who were to be exploited from those who were protected from that exploitation (Mendoza 2016). Quijano pinpoints two crucial aspects that influence the notion of the Other: on the one hand, the control over workforce and production means that 'all forms of unpaid work were to be ascribed to the colonized races' while, on the other hand, all paid endeavours, jobs or services are given to the 'colonizer's race' (2000: 208). The film stages said violence as it portrays the peasants' vulnerability within the coffee plantation, while it points at Manuel and Ignacio as the middlemen, themselves indigenous, whereas the farm owner, presumably a ladino, does not even appear in the film. Direct labour exploitation coupled with the systematic destruction of written memory provoked the vulnerability portrayed by Ixcanul's characters, as they are deprived of the tools to stage their demands.

While colonisation may be defined by military facts, coloniality stands as a concept in an epistemological dimension (Mendoza 2016). It is the mental framework that prevails and continues to reproduce power relations centuries after the material conditions have ceased to exist. The coloniality of power maintains its dominating agency long after colonialism has been eradicated, profoundly permeating the consciousness as well as the social relations of all subjects involved (Mendoza 2016). As Arturo Arias states:

Coloniality of power means the production of identities based on race, conjoined with a hierarchy between European and non-European identities in which the first have 
oppressed all others, together with the construction of mechanisms of social domination designed to preserve this historical foundation and social classification.

$(2012,110)$

Both postcolonial and decolonial frames of thought diagnose the epistemic violence intrinsic to occidental knowledge. The former questions the possibility of the subaltern's voice in the context of dialogue between European and Asiatic thought traditions. The latter, however, holds the certainty that the subaltern can speak (Arias 2012) but can it perform? Can it stage its agency?

\section{María's voice}

The fundamental elements of Ixcanul's cinematographic language are how the characters are built and the most important axis of the characters' interactions is the mother-daughter relationship. The affective relation between María and Juana is central to the construction of meaning of the film: more than half of Ixcanul's scenes are built on the interaction between these two women, including the first and last shots of the film. In most of these shots, their bodies appear in a medium two-shot, which expresses both women's physical intimacy as well as their interdependence. Juana shows herself as a future version of María, projecting what the young woman will be in twenty years. Through Juana, María learns how to encourage the hogs to breed, work in the field and the kitchen, carry firewood, bring offerings to the volcano and collect the fowl's eggs. María learns how to work and how to talk. The few moments when María is by herself, or with Pepe, her sensuality also arises showing her curiosity and autonomy. The camera portrays her persuasive expressions, as well as her curiosity in medium close-up shots, while she stares at the breeding hogs, when a travelling shot through the coffee plantation finds 
her kissing Pepe, laying on the bed while her parents are having sex in the neighbouring bed or picking coffee while flirting with Pepe.

Their daily life on the farm where they work is profoundly linked with nature and Juana guides her daughter, advises her and demands her attention as, for example, when María drifts away while praying. Juana is constantly dragging her daughter into conversations and articulates María's gestures and actions by giving them verbal interpretation. For instance, when María worries about upsetting her father due to her pregnancy by Pepe, Juana tries to console her saying Manuel (the father) will overcome his anger when he sees the 'boy'. A simple nod from María triggers Juana's conclusion: 'I don't think so', María says, 'Is it because it is a 'girl'?' Juana clarifies and María agrees. 'So, you did count your moons,' Juana concludes, showing how mother and daughter handle the lunar calendar with dexterity. The treatment of both charactersfocuses on their knowledge and cultural meanings, removing them from the binaries that could deem them 'anti-modern, bounded by place and anachronism'; even if they belong to an enclosed diegesis, they show transgressive knowledge that saves them from the 'salvage ethnography’ (Gleghorn 2017: 167).

Juana's voice is clear: she expresses her gratitude, demands and builds contexts and situations verbally. A scene, in which this becomes apparent, is in the third sequence, in which Juana and Manuel offer Ignacio a meal. The meal gathers both families together in an engagement ritual; Ignacio is there to define the terms of the marriage. Juana does not hesitate to promote her daughter's virtues, which she exhibits as an example of her own merit. The meal is framed in a medium group shot that often portrays María at the end of the table (see Figure 3), half smiling at her mother's wit and hidden behind all the toasting glasses; her opinion or point 
of view is hardly taken into account. This does not seem to bother her, she trusts and follows her mother's will.

$<$ INSERT FIGURE 3>

Within the context of the family, Juana is a respected voice: 'Touch me,' she tells her husband when searching for sex while lying in the bed next to their daughter; 'I will think of something, as I always do,' she says when Manuel worries that they will be expelled from the farm due to María's unfaithfulness to Ignacio. As a character, Juana shows a direct connection between her own thoughts and feelings and the human and social context that surrounds her; however, her communicative drive is frustrated when the injustice they face becomes evident. The relevant authorities do not listen to Juana: the only language she knows, Kaq'chikel, is ignored. Furthermore, her voice is distorted in the translations that Ignacio, the only bilingual character, creates based on her words. No public servant - not the social worker, doctor or lawyer Juana consults - even considers the need to understand Juana. The characters' monolingual circumstance leaves them vulnerable. The film places that fragility in the mise-enscène which assumes a wider angle to frame the brutal system that maintains oppression. In a three medium shot (see figure 4) Juana looks confused in front of the legal authorities: 'They will find the baby?' she asks Ignacio, to which Ignacio answers convincingly, in Kaq' chikel 'They are trying'. Meanwhile, the lawyer queries 'What is the Madame saying?', 'That she wants to leave' answers Ignacio, distorting Juana's petition to find her granddaughter.

$<$ INSERT FIGURE 4> 
On three different occasions, Juana tries to make her voice heard by these institutions. First, when the social worker comes to confirm - in a census - the sanitary services they have at the farm. On this occasion Juana talks to the state employee assuring them that the house where they are at is her address. The enquiry comes in the middle of a tense moment, as Ignacio has recently been informed that María is pregnant by another man. When asked for an interpretation from Kaq' chikel to Spanish, Ignacio translates Juana's words 'this is our address' into 'They are leaving', ambiguously pushing the family away from the farm, without telling them. A second misunderstanding arises when María is in agony owing to a snake bite. Once in the hospital, while María's health is in jeopardy, Juana tries to ask the doctor for her daughter's status to receive only a blunt denial from the health authority; the mother approaches the doctor asking about María's health but he sends her away, neglecting her professional duties based on the because Juana does not understand Kaq' chikel. The third misunderstanding Juana faces is the most serious of all, as it happens when the fake corpse of the baby is found and they go to the legal authorities. Juana pursues support to find the baby while the lawyers threaten her daughter on charges of infant trafficking. In these episodes the language barrier provokes her dependence on Ignacio: if she wants to communicate with the social workers, doctors or lawyers, she must blindly trust Ignacio's dual linguistic ability to honestly interpret back and forth. Ignacio's hidden agenda - all he wants is to marry María and guarantee a stepmother for his three children - triggers the messages' interception as he changes the meaning of what the professionals say to Juana and vice versa. As such, Juana loses agency, and she ends up being oppressed. Her condition as the other, to the institutions and state resources, becomes the axis of the story. 
The way the narrative is plotted presents the world to us on her terms, that is in Kaq' chikel, at her pace, with her music. From the second sequence she is presented to us as a proud witty mother with a profound understanding of natural cycles and corporeal joys. Juana's character expresses her point of view, crucial elements of her consciousness as well as the limitations, particularly those derived from her illiteracy. It is within the performance of this perspective that the mise-en-scène portrays the clash between her position as a woman under the weight of patriarchy and racism, while also portraying her agency and, consequently, that of María. That clash is key to the coloniality of power, where those conquered were condemned to live in the place of unbeing, stripped of humanity, rights and self-determination (Mendoza 2016). This situation, writes Quijano, disrupted all aspects of indigenous society, including gender, work, colonial authority relations, as well as social reorganization within public and private institutions (Mendoza 2016). This is the wall that Juana repeatedly crashes into.

Bustamante addresses the performativity of the drama stressing that it is crucial to the task of directing: 'the great thing about cinema is that you can't say what the characters think, you have to let them show it on their own terms' (Bustamante 2015a). In this sense, Ixcanul contributes to a kind of cinema that breaks from Spivak's description of the subaltern's voicejourney: it never remains solely in the constative and rather jumps forward to the performative act. The translation is performed by the subaltern herself. The character is shown in its vulnerability and limitations while at the same time in its struggle to overcome them. Both the rationale and the methodology used to accomplish the leap from constative to performative is traversed by the 'porous dynamic of authorship' (Gleghorn 2017: 172); every scene and dialogue in Ixcanul negotiates a structure to serve María's point of view. Throughout the film, María exercises her agency: she smiles, masturbates, searches for Pepe, undresses, packs her bags, digs 
up the coffin where her baby is meant to be and finally expresses her opinion at two crucial moments in the film. We see an example of this when, at the beginning of the third act, María is determined to scare away the snakes, risking her life in an act of blind trust of the anecdotes her mother had just recounted. On this occasion, Juana disagrees while Manuel sees an opportunity to solve a difficult problem. Juana ends up giving in to María's will to help even if she is not convinced. It is worth noticing that when the snake ends up biting María, Juana is the first to call for the help of science: instead of insisting on a spiritual ritual she quickly sets off to the hospital with her daughter.

Finally, within the construction of the characters, their arc and voice, the last words María pronounces are jaja' $k^{\prime}$ a maja(ni) yech', '(s)he doesn't speak yet' and achike yiruq'ax yich'o ke re 'Who would understand me if I talked like that?' in answer to Manuel's attempt to console her when he says her child must be living in the United States, in a big house with a garden and must by now be talking in English. At the beginning of the film she would only mumble words, always asking rather than affirming, for instance, asking Pepe if he could take her with him, kinak'ama' (aw)ik'in? However, María's last words complete the character's dramatic arc - now she speaks her mind in a style very close to Juana's, choosing to challenge her father when affirming her lost child is a female, cannot speak yet and even if she, did who would understand her speaking English? Manuel's silence while the three lay at the back of the truck on the way back from the lawyer's office to the farm (see figure 5) shows he is resigned.

\footnotetext{
$<$ INSERT FIGURE 5>

$<$ INSERT FIGURE 6>

$<$ INSERT FIGURE 7>
} 
The film starts and finishes with the same medium close-up shot (See figures 6 and 7), which show María, while Juana is cleaning her face and placing a cloth flower crown on her head, the first time as a formal dress, the last time as a bride's outfit. The first medium close-up shot works as a prolepsis of what will happen next. Both women run the farm, breeding, killing, cooking the hogs, and then dressing for Ignacio. The relationship between María's dress when she is preparing to receive Ignacio and the details of her preparation orientate us within the plot's chronology inside the filmic narrative. María's facial expression exhibits cultural submission as it establishes the profile of both characters: Juana is officious and quick, curating her daughter's outfit; María is still and obedient, following her mother's instructions. The last shot of María is framed using the same medium close-up. On this second occasion, however, and given the story we have just witnessed, the emphasis is placed on her defeated facial expression. The same pantomime, the same framing, the same characters: it completes a cycle of time. María can speak, and her dramatic arc drives her to do so physically, culturally and even linguistically, by the end of the film. The Casa de Producción and Bustamante bring her voice into the mise-en scène in the same manner as they observe the context in which María's and Juana's voices have clashed against the institutions paralysing them. María's voice gives her speech as she is seen to disagree with the patriarchal establishment. Bustamante manages to convey this feeling via a performative stage, leaving it frustrated; the mise-en scène allows María to build her agency in an exercise of polyphony where the negotiated meaning remains with Juana and María, while it frames the break in the action by a context that no longer depends on these characters. It thus moves the action to the wall against which María collides, portraying this conflict over again. 
The film therefore replaces the question 'Can María speak?' and instead enunciates the more telling question: Are we even capable of hearing her?

\section{References}

Arias, A. (2012), ‘Afterword’. In d'Lión, Luis Time Commences in Xibalbá. Tucson: The University of Arizona Press.

Avellán Troz, K. (2016), e-mail to author, 4 July.

Box Office Mojo (2017), 'Ixcanul Domestic Box Office' http://www.boxofficemojo.com/movies/?page=intl\&id=ixcanul.htm. Accessed 13 March 2017.

Bustamante, J. (2015), Ixcanul. La fuerza del volcán, Guatemala: La Casa de Producción.

- (2015a), in person interview, University College London, 17 October,.

- (2015b), in person interview, Alliance Francaise, London, 18 October.

Colop Sam, L. E. ed. (2008), Popol Wuj: Traducción al español y notas de Sam Colop. Guatemala: Pace-GTZ, Editorial Cholsamaj. 
Cortés, M.L. (2018), 'Filmmaking in Central America: An Overview' in Studies in Spanish \& Latin American Cinemas 15:2, pp. 137-55.

El Confidencial (2016), Europa tiene que ser un santuario para refugiados. Entrevista a Rigoberta Menchú http://www.elconfidencial.com/cultura/2016-08-02/rigoberta-menchu-premionobel-paz-refugiados-cine-cultura_1240359/. Accessed 20 February 2017.

Delgado, M., Hart, S. \& Johnson, R. (eds.) (2017), A Companion to Latin American Cinema. Chichester, West Sussex; Malden, MA: Wiley Blackwell.

Echeverría, M. (2015), “Digna Ixcanul” in Salivario http://salivario.blogspot.co.uk/2015/09/dignaixcanul_96.html. Accessed 13 February 2017

Fundacine (2015), Evaluación anual 2014-2015. San José: Fundación para el desarrollo del cine.

Gleghorn, C. (2017), 'Indigenous filmmaking in Latin America', in: Delgado, María, Hart, Stephen \& Johnson, Randall (eds) (2017), A Companion to Latin American Cinema. Chichester, West Sussex; Malden, MA: Wiley Blackwell.

Guha, R. (2003), La historia en el término de la historia universal. Barcelona: Crítica

Hjort, M., \& Duncan P., (eds.) (2007), The Cinema of Small Nations. Edinburgh: Edinburgh 
University Press.

Quijano, A. (2000), 'Colonialidad del Poder, eurocentrismo y América Latina’, in E Lander (ed.), La colonialidad del saber: eurocentrismo y ciencias sociales. Perspectivas Latinoamericanas, Buenos Aires: CLACSO.

La casa de producción (2017), Website http://lacasadeproduccion.com.gt/en/home/ Accessed 13 December 2017.

Margilies, I. (2011), "Reenactment and A-filiation in Andrea Tonacci's Serras da Desordem.", in: Cinephile, 7(2): 4-13.

Mejía, S. (2017), La película guatemalteca "Ixcanul" ingresa al mundo de Netflix. http://www.soy502.com/articulo/pelicula-guatemalteca-ixcanul-ingresa-al-mundo-netflix153. Accessed 13 August 2017.

Mendoza, B. (2016), Colonialidad del Género y Poder: De la Postcolonialidad a la Decolonialidad. Canal UCR https://www.youtube.com/watch? $v=s l 8 B U k s Q t O Y \& t=3 \mathrm{~s}$. Accessed 20 August 2016.

Morton, S. (2007), Key Contemporary Thinkers: Gayatri Spivak. Cambridge/ Malden, MA: Polity. 
Pitney, N. (2016), This Mayan-Language Film Is The Best Thing In Theaters Right Now http://www.huffingtonpost.com/entry/ixcanul-jayrobustamante_us 57c858dae4b0a22de0948cfb. Accessed 13 February 2017.

Salguero Rodas, C. (2016), 'Estado y Sociedad en Guatemala: inclusión y exclusión' in R. J. Viales and D. Díaz Arias (eds), Historia de las desigualdades sociales en América Central. Una vision interdisciplinaria, siglos XVIII-XXI, San José: Centro de Investigaciones Históricas de América Central, pp. 399-415.

Sánchez, J.L. (2018), e-mail to author, 8 January.

Scherstuhl, A. (2016), 'Ixcanul' and a Stellar Doc Find Indigenous Life Pitted Against Modernity http://www.villagevoice.com/film/ixcanul-and-a-stellar-doc-find-indigenous-life-pittedagainst-modernity-8985977. Accessed 13 February 2017.

Spivak, G. (1988), 'Can the Subaltern Speak?' in C. Nelson and L. Grossberg (eds), Marxism and the interpretation of Culture. Chicago: University of Illinois Press.

Tedlock, D. (1985), The Popol Vuh: The Definitive Edition of the Mayan Book of the Dawn of Life and the Glories of Gods and Kings, New York: Touchstone. 
Xinico, S. (2015), 'El syndrome Ixcanul ¿entre realidad y película? -Parte I' in: https://culturalesguatered.wordpress.com/2016/09/26/el-sindrome-de-ixcanul-entrerealidad-y-pelicula-parte-i/ Accessed 13 December 2017.

- (2016), 'El syndrome Ixcanul ¿entre realidad y película? -Parte II' in:

http://lahora.gt/sindrome-ixcanul-realidad-pelicula-parte-ii/ Accessed 13 December 2017.

\section{Contributor Details}

$\mathrm{PhD}$ Candidate at University College London. Amanda has worked as Adjunct Lecturer at the University of Costa Rica and written, directed and produced independent short films as well as a TV series about Film Appreciation. Currently writes the research Repeating Islands and develops the homonymous documentary, about the political economy and aesthetic trends of selected Central American and Caribbean films for the Documentary track $P h D$ at the School of European Languages, Culture and Society (Spanish, Portuguese and Latin American Studies), in University College London.

${ }^{1}$ Most of the crew was gathered from Bustamante's close collaborators: the make-up person is a professional of Japanese origin (Sato), the editor is of Belgian and Guatemalan origin (Díaz), the camera person and two of the producers are Argentinian (Arteaga, Peredo and Tenenbaum), another producer is Spanish (Nofuentes) and Bustamente himself is Guatemalan-born and France based. The production, privately and publicly funded from France, Guatemala, Spain and the Film Fund Cinergia, shows the stories of the Mayan community it represents (Bustamante 2015). All professionals gather around La Casa de Producción, a production company founded by Bustamante. 
${ }^{2}$ Some films had been made in Kiché such as Maya, Where the Sun in Born (Jiménez, 2013) or Mam, such as La casa más grande del mundo/ The Greatest House in the World (Bojórquez and Carreras) or have partial dialogues in Kaq' chikel, Kechi, Tzotzil or Tz'utujil like El regreso de Lencho/ The return of Lencho (Fernández, 2010), Numaj Ruq'ii Q'aq Bajlam/ The myth of time (Jaguar X, 2008) or El Norte/ The North (Nava, 1983). Ixcanul is the first film to be entirely spoken in Kaq' chikel.

${ }^{3}$ The distribution range across five continents, is unusual for most Central American films: Turkey, Mexico, Former Yugoslavia, Japan, US, Italy, Middle East, Denmark, Dominican Republic, Greece, China, Norway, German speaking Europe, Australia, Vietnam, Puerto Rico, by Film Factory, Guatemala by La Casa de Producción and Central America (with the exception of Guatemala) by Pacifica Grey.

${ }^{4}$ Within the distinction of Mayan communities in Guatemala it is worth mentioning that despite a systematic attempt to narrate K'iche's and Kaq' chikels as enemies, they both hold the same cultural root and marginality. The K'iche' community outnumbers the Kaq'chikel by almost 2 million speakers, having around 2.3 million in total. Both communities see themselves as Maya, despite their distinct languages.

${ }^{5}$ The director explains his deficiency in Kaq' chikel language, arguing that even if he learnt it through his sitter as a child, she would have stopped him from speaking it while everyone else would celebrate when he spoke French in addition to Spanish (Bustamante a 2015). 
${ }^{6}$ Quijano describes the concept of race as 'literally an invention' (203) quoting his own work, Jonathan Mark's and José Carlos Mariátegui's: 'The [...] the category of color [...] just like the invention of the particular category white, requires exhaustive historical investigation $[\ldots]$ there is no trace of these categories in the chronicles or other documents of the first hundred years of Iberian colonisation in the Americas'. To support the idea that racism started with European migration to the American continent Quijano points out: '[D]espite those who would become European in future knew the future Africans since the times of the Roman Empire and even the Iberians were more or less familiar with them long before the Conquest, they never thought of them in terms of race before the apparition of America. In fact, race is a category applies for the first time to the "Indians" and not to "blacks"'. (Quijano 2000, 203)

${ }^{7}$ Translated from Kaq' chikel by Raina Heaton. 